\title{
Research projects in family medicine funded by the European Union
}

\author{
Ivančica Pavličević ${ }^{1}$, Lana Barać ${ }^{2}$ \\ ${ }^{1}$ Department of Family Medicine \\ University of Split School of Medicine \\ Split, Croatia \\ ${ }^{2}$ Research Office University of Split \\ School of Medicine, Split, Croatia \\ Corresponding author: \\ Ivančica Pavličević \\ University of Split School of Medicine \\ Department of family medicine \\ Šoltanska 2, 21000 Split \\ Croatia \\ ipavlice@mefst.hr \\ Tel.: + 38521557823 ; + 385915902439 \\ Fax.: + 38521557820
}

Received: 19 November 2013

Accepted: 12 March 2014

Copyright (C) 2014 by

Academy of Sciences and Arts

of Bosnia and Herzegovina.

E-mail for permission to publish:

amabih@anubih.ba
Objective. This study aimed at synthesizing funding opportunities in the field of family medicine by determining the number of family medicine projects, as well as number of project leaderships and/ or participations by each country. This was done in order to encourage inclusion of physicians in countries with underdeveloped research networks in successful research networks or to encourage them to form new ones. Methods. We searched the Community Research and Development Information Service project database in February 2013. Study covered the period from years $1992-2012$, selecting the projects within the field of general/family medicine. The search was conducted in February 2013. Results. First search conducted in the CORDIS database came up with a total of 466 projects. After excluding 241 projects with insufficient data, we analysed 225 remaining projects; out of those, 22 (9.8\%) were in the field of family medicine and 203 (90.2\%) were from other fields of medicine. Sorted by the number of projects per country, Dutch institutions had the highest involvement in family medicine projects and were partners or coordinators in 18 out of 22 selected projects (81.8\%), followed by British institutions with 15 (68.8\%), and Spanish with 10 projects $(45.5 \%)$. Croatia was a partner in a single FP7 Health project. Conclusion. Research projects in family medicine funded by the European Union show significant differences between countries. Constant and high-quality international cooperation in family medicine is the prerequisite for improvement and development of scientific research and the profession.

Key words: International projects, Project database, Family medicine, Cooperation.

\section{Introduction}

The European Union funding of research projects includes funding opportunities available through Lifelong Learning Program (LLP), 7 cycles of Framework Program (FP), and projects within the framework of Instrument for Pre-Accession Assistance (IPA) $(1,2)$. Framework Programs have been in existence since 1984, and have so far com- pleted seven cycles (3). The Seventh Framework Program was active for seven years, since January $1^{\text {st }} 2007$, until the end of 2013. The goal of the FP7 projects Health group was to improve the health of European citizens and focus on solving global health problems. It encouraged collaborative research, with the objective of establishing excellent research projects and networks able to attract researchers and investments from 
Europe and the entire world. Programs from this trans-national collaborative research encouraged development and validation of new therapies, methods of health promotion and disease prevention, including promoting health of children, healthy aging, diagnostic tools and medicinal technologies, as well as efficient and sustainable health care systems. However, family medicine as a subset of health care in general was one of the least-funded fields, indicating the need for increased funding in the future.

Although research in family medicine in the Republic of Croatia has a longlasting tradition (4), a sustainable research network does not yet exist. There are many reasons for this, but the main ones related to the topic of this study are the inadequate national funding reserved for this field, lack of continuity, as well as an insufficient number of quality researchers. So far there have not been enough quality studies conducted in the field of family medicine in Croatia (4). Receiving additional opportunities to access the EU funding would greatly help in addressing all of these three issues. The chances for accessing the EU funding will hopefully be greatly improved by the recent (2013) joining of Croatia to the EU.

The aim of this study was to provide synthesis of funding opportunities in the field of family medicine by determining the number of EU funded projects in family medicine, their number and project leaders by country, and number of institutions from that country were included in these projects in order to encourage inclusion of physicians in countries with underdeveloped research networks in successful research networks or to encourage them to form new ones. This might influence further choices of project partners (whether it is high-achieving countries' institutions reaching out to those just starting out, or vice versa) when assembling teams for future projects, as well as the future allocation of funds by policy-makers. It should also provide any neutral observers with a quick snapshot of the current state within the field of family medicine reasearch.

\section{Methods}

The CORDIS (Community Research and Development Information Service) project database includes all public information (project factsheets, publishable reports and deliverables), editorial content communication and exploitation and comprehensive links to external sources such as open access publications and websites. We independently searched the CORDIS project database for the EU funded projects available in the database for the period from 1998 to 2012 using the following keywords: family medicine, general practice, family medicine health care, and primary health care. For the purpose of this article, we defined family medicine in the European area as a subset of primary health care, which involves a comprehensive and holistic provision of preventive, diagnostic and health treatment services to all patients in the practicioner's community.

All projects that did not have available data on project type and duration, the state coordinator of the project and the participating countries were excluded. We analysed abstracts of all remaining projects, and selected those within the field of general/ family medicine for further analysis. Due to the number of eligible projects containing all the required data being very low, we expanded the search to the period of 19922012 and repeated this process. All disagreements have been resolved by discussion and consensus.

\section{Results}

First search conducted in the CORDIS database came up with a total of 466 projects. After excluding 241 projects with insufficient data, we analysed 225 remaining proj- 
ects and found that out of those, 22 (9.8\%) were in the field of family medicine and 203 (90.2\%) were from other fields of medicine. Of those 22 projects in the field of family medicine, 11 were FP7 projects, 2 FP6, 5 FP5, and 1 each from the following groups: Leonardo da Vinci (1995-1999), Peco/Copernicus (1992-1994), STD 3 (1992-1995) and AIM 2 (1990-1994). The FP7 cycle is further divided into specific programmes. Out of 11 FP7 projects, 10 were funded within the specific programme "Cooperation", and 1 project was funded within the specific programme "Ideas".

When sorted by the number of projects per country, Dutch institutions had the highest level of involvement in family medicine projects and were partners and/ or coordinators in 18 out of 22 projects examined (81.8\%), followed by British institutions with 15 projects $(68.8 \%)$, and Spanish with 10 projects (45.5\%) (Table 1 ).

Dutch researchers coordinated $8(36.36 \%)$ projects, and were partners in 15 (68.18\%) projects. The highest number of institutions included in a single project $(\mathrm{n}=38)$ cooperated in the project „The care and management of services for older people in Europe network", which also included the highest number of institutions per country $(n=3.8)$ (Table 2). Other than 19 countries with a medium level of involvement, there are also

Table 1 Participation of European countries ${ }^{*}$ in family medicine projects $(n=22)$ financed through $\mathrm{FP7}^{\dagger}$, $\mathrm{FP}^{\ddagger}$, FP5 ${ }^{\S}$, LEONARDO DA VINCI, PECO/COPERNICUS, STD3" and IM2" programs, sorted by number of project leaderships ** for each country

\begin{tabular}{|c|c|c|c|c|}
\hline \multirow[t]{2}{*}{ Country } & \multicolumn{4}{|c|}{ Number of projects } \\
\hline & By country & Leaderships & Participations & Institutions \\
\hline Netherlands & 18 & 8 & 15 & 36 \\
\hline United Kingdom & 15 & 4 & 13 & 38 \\
\hline Denmark & 7 & 2 & 7 & 10 \\
\hline Spain & 10 & 1 & 11 & 17 \\
\hline Sweden & 9 & 1 & 7 & 13 \\
\hline Italy & 9 & 1 & 8 & 10 \\
\hline Belgium & 8 & 1 & 7 & 11 \\
\hline Greece & 4 & 1 & 4 & 9 \\
\hline Germany & 7 & 1 & 7 & 9 \\
\hline Slovenia & 5 & 1 & 4 & 5 \\
\hline Ireland & 1 & 1 & 1 & 5 \\
\hline Austria & 5 & - & 5 & 6 \\
\hline France & 5 & - & 5 & 5 \\
\hline Poland & 4 & - & 4 & 6 \\
\hline Finland & 4 & - & 4 & 6 \\
\hline Portugal & 4 & - & 4 & 4 \\
\hline Lithuania & 2 & - & 2 & 3 \\
\hline Norway & 2 & - & 2 & 2 \\
\hline Czech Republic & 2 & - & 2 & 2 \\
\hline Estonia & 2 & - & 2 & 2 \\
\hline Switzerland & 2 & - & 2 & 2 \\
\hline Mali & 1 & - & 1 & 2 \\
\hline
\end{tabular}

*One participation/institution by: Croatia, Cyprus, Turkey, Malta, Iceland, Hungary, Romania, Bulgaria, Ukraine, Slovakia, Russia, Israel, Canada, Argentina, Botswana, South Africa, Sudan, Uganda, Philippines, Vietnam, Bangladesh; ${ }^{\dagger}$ Seventh Framework Programme; ${ }^{\ddagger}$ Sixth Framework Programme; ${ }^{\S}$ Fifth Framework Programme; "Life sciences and technologies for developing countries; $\uparrow$ Specific program of research and technological development; **Many countries were simultaneously both the project leader and the participant (through another institution from the same country) within the same project. Thus, the total number of projects for a given country does not equal the sum of its leaderships and participations. 
Table 2 General data about programs included in the study

\begin{tabular}{|c|c|c|c|}
\hline \multirow{2}{*}{ Project name } & \multirow{2}{*}{ Program } & \multicolumn{2}{|c|}{ Number of institutions } \\
\hline & & By project & By country \\
\hline $\begin{array}{l}\text { Polypharmacy in chronic diseases: Reduction of Inappropriate Medication } \\
\text { and Adverse drug events in elderly populations by electronic Decision } \\
\text { Support }\end{array}$ & FP7 & 6 & 1.2 \\
\hline Quality and costs of primary care in Europe & FP7 & 6 & 1.2 \\
\hline $\begin{array}{l}\text { New and more individualised population-based screening for cardiovascular } \\
\text { disease; from a RCT including self-assessments, primary care and coronary } \\
\text { artery calcification score to modelling risk-benefit }\end{array}$ & FP7 & 2 & 2 \\
\hline REsearch into POlicy to enhance Physical Activity & FP7 & 10 & 1.25 \\
\hline $\begin{array}{l}\text { Self-care Support for People with Long Term Conditions, Diabetes and Heart } \\
\text { Disease: A Whole System Approach }\end{array}$ & FP7 & 7 & 1.17 \\
\hline $\begin{array}{l}\text { Learning from international networks about errors and understanding safety } \\
\text { in primary care }\end{array}$ & FP7 & 12 & 1.5 \\
\hline $\begin{array}{l}\text { Assessing the over-the-counter medications in primary care and translating } \\
\text { the theory of planned behaviour into interventions }\end{array}$ & FP7 & 11 & 1.38 \\
\hline Human Resources for Primary Health Care in Africa & FP7 & 9 & 1.13 \\
\hline $\begin{array}{l}\text { Improving the Continuity of patient care Through Identification and } \\
\text { implementation of Novel patient handoff processes in Europe }\end{array}$ & FP7 & 9 & 1.5 \\
\hline Optimizing delivery of health care interventions & FP7 & 19 & 1.9 \\
\hline $\begin{array}{l}\text { The appropriateness of prescribing antibiotics in primary health care in } \\
\text { Europe with respect to antibiotic resistance }\end{array}$ & FP7 & 14 & 1.56 \\
\hline $\begin{array}{l}\text { Changing behaviour of health care professionals and the general public } \\
\text { towards a more prudent use of anti-microbial agents }\end{array}$ & FP6 & 12 & 1.71 \\
\hline $\begin{array}{l}\text { Health alliance for prudent prescribing, yield and use of antimicrobial drugs in } \\
\text { the treatment of respiratory tract infections }\end{array}$ & FP6 & 15 & 1.67 \\
\hline $\begin{array}{l}\text { Implementation of patient involvement instruments to improve general } \\
\text { practice care for older people in Europe }\end{array}$ & FP5 & 14 & 1.27 \\
\hline $\begin{array}{l}\text { Prediction of future episodes of depression in primary medical care: } \\
\text { development of a risk factor profile }\end{array}$ & FP5 & 5 & 1 \\
\hline The aged in home care project & FP5 & 9 & 1 \\
\hline The care and management of services for older people in europe network & FP5 & 38 & 3.8 \\
\hline Primary health-care in later life: improving service in Bangladesh and Vietnam & FP5 & 4 & 1 \\
\hline Learning organised through teams & $\begin{array}{l}\text { LEONARDO } \\
\text { DA VINCI }\end{array}$ & 5 & 1 \\
\hline Comparative study on task profiles of general practitioners in Europe & $\begin{array}{l}\text { PECO/ } \\
\text { COPE- } \\
\text { RNICUS }\end{array}$ & 5 & 1 \\
\hline $\begin{array}{l}\text { Collaborative project on community drug use: enhancing the impact of } \\
\text { essential drugs programmes }\end{array}$ & STD 3 & 5 & 1.25 \\
\hline Logic Engineering in General Practice, Oncology and Shared Care & AIM 2 & 8 & 1.33 \\
\hline
\end{tabular}

21 countries (including Croatia, the new EU member state), both from the EU area and beyond, that have successfully applied for and participated in a project together through a single institution.

\section{Discussion}

Our results showed that the Netherlands was the country with the largest number of leaderships and partnerships in the EU funded 
projects in the field of family medicine. This could be the result of a long-lasting tradition of cooperation networks between the family medicine research work in Netherlands and other EU countries. The Netherlands School of Primary Care Research (CaRe) is a center of research in primary care and also a virtual institute which promotes medical doctor and doctoral $(\mathrm{MD} / \mathrm{PhD})$ programs for primary care (family medicine, health science, epidemiology, ethics, medical informatics, nursing). Founded in 1995, it is recognized by the Royal Netherlands Academy of Sciences as a research center of excellence. The research program focuses on promotion and health education, determinants of long-term outcome of illness, effectiveness of diagnostic and therapeutic interventions, quality of care, and international aspects of primary care. Three practice-based research networks are linked to the research program (5). By cooperating with almost all European and some Asian countries, the family medicine programs of Netherlands have demonstrated great openness, cooperativeness, and readiness for a high level of international cooperation.

So far, Croatia was a partner in a single FP7 Health project related to the field of family medicine. In 2013, Croatia became a full member of the European Union which will, we hope, contribute to its better and higher quality cooperation in the field of all European research projects. Improving the overall level of cooperation is very important. Learning from the Dutch example would be a fine start. The existing four research centres (one department of family medicine at each of the four medical schools in Croatia), should establish close cooperation and coordination of research work. They should also engage in joint applications for programs (in partnership with the most successful institutions from different countries in this field) in order to establish continuity.

\section{Limitations of the study}

It would have been useful to additionally analyse the number of family medicine practitioners in the listed countries to determine its possible correlation with the number of projects but, sadly, there is not enough data available for this. This study was limited by the poor data availability concerning all of the project participants for earlier project cycles. Many otherwise eligible projects (466) listed only the country of the project leader and nothing else and thus had to be excluded, bringing the count down to 225 . Also, it is possible that there is a time lag between studies beginning and their entry into the database, so studies which began at the very end of 2012 would not have appeared by February 2013, when the final search was conducted.

\section{Conclusion}

Albeit our study is a modest snapshot analysis, the approach we employed revealed interesting results, which can serve as an indicator of the state of family medicine research funding in a given country. It may be useful to widen this approach by analysis of the level of correlation of number and size of grants won by different countries with their respective scientific production, schemes of training, relative number and organization of physicians, workload and a number of other factors that potentially affect scientific excellence in family medicine (and other parts of medicine). This is of utmost importance for the countries which appeared unsuccessful in this analysis because the success in winning European Union research grants and participating in them may indeed indicate the necessity to review the state of art in this important health profession in the country in question. 
Acknowledgements: Heartfelt thanks to Professor Matko Marušić for the idea, encouragement, and great help during writing.

Authors' contributions: Conception and design: IP and LB; Acquisition, analysis and interpretation of data: IP; Drafting the article: IP and LB, Revising it critically for important intellectual content: LB and IP.

Conflict of interest: The authors declare that they have no conflict of interest.

\section{References}

1. Ministry of Science, Education and Sport [homepage on the Internet]. MSES; (c) 2004 - 2013 [updated 2008 Jan 03; cited 2013 Jun 12]. Second Congress of Croatian scientists from the country and abroad; (C) 2007; Thematic Unit: European and International Projects; Final document.
Available from: http://public.mzos.hr/Default. aspx?sec $=2625$.

2. University of Zagreb, Faculty of Organization and Informatics, Center for International Projects [homepage on the Internet]. (c) Faculty of Organization and Informatics, Varaždin; 2013 [cited 2013 Jun 12]. International Funding. Available from: http://www.projekti.hr/node/58.

3. Ministry of Science, Education and Sport [homepage on the Internet]. MSES; (c) 2004 - 2013 [updated 2013 Jun 03; cited 2013 Jun 12]. Seventh Framework Programme. Available from: http:// public.mzos.hr/Default.aspx?sec=2668.

4. Vrdoljak D, Petric D. A proposal for enhancement of research capacities in Croatian general practice. Acta Med Acad. 2013;42(1):71-9.

5. van Weel C, Rosser WW. Improving health care globally. A critical review of the necessity of family medicine research and recommendations to build capacity. Ann Fam Med. 2004;2(Suppl 2):S5-16. 